\title{
Performance of Twenty Cassava Cultivars on Marginal Peats and Peaty Clays of Guyana ${ }^{1}$
}

\author{
Abdul H. Wahab, Imran Hassan, and M. A. Lugo-López ${ }^{2}$ \\ ABSTRACT
}

A cassava trial including 20 cultivars was conducted to assess the suitability of Guyana's marginal Anira peat No. 20 and Inki clay No. 100 for this crop during a 12-mo growing period. Germplasm material was obtained from Brazil, Colombia, Mexico, Puerto Rico, and Guyana. Cultivars Tacana and Iracema (Brazil) ranked above all others on both soils, producing $28 \mathrm{t} /$ ha fresh roots on the Anira peat and $24 \mathrm{t} /$ ha on the Inki clay. All introduced cultivars outyielded their local counterparts. The highest yielding native cultivar, Badwoman, produced 12 and $10 \mathrm{t} / \mathrm{ha}$ of fresh roots on the Anira peat and Inki clay, respectively. Cultivar M Col 673 had the highest root dry matter content, about $40 \%$ for both soils. Edible fresh matter content (ratio of peeled to unpeeled root) averaged 0.85 and was essentially the same for all cultivars. A highly significant relationship was obtained between total plant weight and root yields on both soils $(r=0.92$ and 0.94$)$, and between harvest index and root yields $(r=0.64$ and 0.81$)$. The number of stems per cutting and stem diameter at harvest were not related to yield. However, number of edible roots per plant was highly correlated with yield $(r=0.69$ and $0.54)$. Root thickness was also related to yield $(r=0.92$ and 0.95$)$ on both soils. Under field conditions, all cultivars stored well for 5 days before primary deterioration began.

\section{INTRODUCTION}

Priorities for determining the feasibility of planting cassava on Guyana's peats and peaty clays were discussed in a previous paper (7). These soils cover approximately one million hectares of essentially unexploited land. They lie south of the coastal clays and, unless drained, are flooded most of the year (5). Soils are extremely acid and contain low levels of plant nutrients. However, when drained and intensively managed, they can be made productive. This was demonstrated by earlier studies in

${ }^{1}$ Manuscript submitted to Editorial Board January 31, 1978.

${ }^{2}$ Former Crop Development Officer and Field Supervisor, respectively, Guyana Sugar Corp., Ltd., and Professor and Soil Scientist, (Ret.), Agricultural Experiment Station, University of Puerto Rico, Mayagüez Campus, Rio Piedras, P.R., now Consultant, Cornell University. This work was financed by the Guyana Sugar Corp., Ltd., with technical support from the Department of Agronomy, Cornell University, Ithaca, N.Y., under USAID research contract ta-c-1104. The authors are indebted to several people for assistance during the course of the work. Messrs. R. A. Wilkins and J. A. S. Harlow were solely responsible for promoting the studies. Frank Dalmada and David Wilkie were helpful in providing logistic support. Michael Joseph and Ralph Persaud assisted greatly in both the laboratory and field. The Engineering Experimental and Field Equipment Departments (Guysuco) greatly assisted in land reclamation and preparation of the site. Many other people at Enmore Sugar Estate willingly gave assistance when needed. Allan Schaff and Dr. B. K. Rai assisted in pest identification and control. Special thanks are due Miss Thecla Gonsalves for typing the manuscript. The authors also acknowledge with deep gratitude the continued support of the Guyana Sugar Corp., Ltd. which enabled them to undertake this work. 
which improved cultivars of cassava yielded up to $30 \mathrm{t} / \mathrm{ha}$ of fresh roots in 12 mo on Anira peats (7).

This paper presents the results of two experiments to evaluate the yield performance of 20 local and introduced cassava cultivars on marginal peats and peaty clays of Guyana.

\section{MATERIALS AND METHODS}

The experiments were conducted at the Enmore Sugar Estate from November 1975 through November 1976. The cultivars were arranged in a randomized block design and replicated five times. Nine of the 20 cultivars, namely, Badwoman, Brancha Butterstick, Bitter Stick, Chinese Stick, Four Month, L.H. 2, R. Singh, Twelve Month, and Uncle Mack were obtained locally. The remaining came from abroad. Cultivars Iracema, Piracununga, and Tacana were promising lines from Brazil, Del País was introduced from Puerto Rico, and the others, i.e., CMG 40, Llanera, M Col 22, M Col 673, M Mex 23, M Mex 55, and M Mex 59 were obtained from the Centro Internacional de Agricultura Tropical, Colombia.

The two soil types are locally classified as Anira peat No. 20, and Inki Clay No. 100. The Anira peat No. 20 (Anira peat hereafter) consisted of dark-reddish-brown peat from the surface to a depth of $120 \mathrm{~cm}$. The surface layer $(0$ to $15 \mathrm{~cm}$ ) consisted of raw to semi-decomposed peatpeaty clay. Hydrogen sulphide was present throughout the $122 \mathrm{~cm}$ profile. Anira peat has a high swell/shrink ratio (50\% or greater) and may undergo spontaneous combusion when dry (5). Relevant soil properties are given in table 1 . The soil is extremely light and porous and, at field capacity $\left(\frac{1}{3}\right.$ bar), it holds 3 times its weight in water. Cation exchange capacity was $18.2 \mathrm{meq} / 100 \mathrm{~g}$.

The Inki Clay No. 100 had a surface matt of 1 to $20 \mathrm{~cm}$ of peaty clay. The upper subsoil was a soft-gray to greenish-gray clay which was underlaid by peat (5). The soil texture was comprised mainly of clay; organic matter constituted 10\% (table 1).

Trial sites were located $3 \mathrm{~m}$ below sea level. Mean annual temperature was above $26.7^{\circ} \mathrm{C}$ with monthly variations of less than $4^{\circ}$. Rainfall amounted to $293 \mathrm{~cm}$ and exceeded the mean by $23 \%$. During the first 3 mo of the experiment, $152 \mathrm{~cm}$ or about $50 \%$ of the total rainfall was recorded. This resulted in a drop of about $20 \%$ in germination. Rainy days constituted $40 \%$ of the trial period. In 6 of the 12 -month growing period there was an excess of moisture in the soil as indicated by a positive atmospheric water balance. On the contrary, sunshine hours totalled 2,333 and ranged from an average of $4.3 \mathrm{hr} /$ day in December to $9.6 \mathrm{hr} /$ day in August.

Trial sites were naturally flooded until early 1974 when drainage 
TABLE 1.-Selected physical and chemical properties of the 0 to $30 \mathrm{~cm}$ soil layer of two soils planted to cassava

\begin{tabular}{|c|c|c|}
\hline & $\begin{array}{c}\text { Soil type } \\
\text { Anira peat No. } 20\end{array}$ & Inki clay No. 100 \\
\hline Clay, \% & 12 & 63 \\
\hline Silt, \% & 22 & 24 \\
\hline Sand, \% & 14 & 3 \\
\hline Organic matter content, $\%$ & 52 & 10 \\
\hline Field capacity at $\frac{1}{3}$ bar, $\%$ & 299 & 58.7 \\
\hline $\begin{array}{l}\text { Permanent wilting percentage at } 15 \text { bars, } \\
\%\end{array}$ & 230 & 40 \\
\hline Bulk density, $\mathrm{g} / \mathrm{cm}^{3}$ & .24 & .94 \\
\hline $\mathrm{pH}(1: 2.5)$ & 3.71 & $4.2 \mathrm{~L}$ \\
\hline Cation exchange capacity, meq/100 g & 18.2 & 15.5 \\
\hline \multicolumn{3}{|l|}{ Available nutrients ${ }^{1}$} \\
\hline Calcium, meq $/ 100 \mathrm{~g}$ & 2.66 & 3.86 \\
\hline Magnesium, meq/100 g & 6.26 & 7.58 \\
\hline Potassium, meq/100 g & .17 & .30 \\
\hline Phosphorus, $\mathrm{p} / \mathrm{m}$ & 37.50 & 1.27 \\
\hline
\end{tabular}

TABLI: 2.-Yields of fresh roots of 20 cassava cultivars at 12 months on marginal pe'at:s and peaty clays of Guyana

\begin{tabular}{lcc}
\hline & \multicolumn{2}{c}{ Fresh-root yield on indicated soil } \\
\cline { 2 - 3 } & Anira Peat No. 20 & Inki Clay No. 100 \\
\hline & $T / h a$ & $T / h a$ \\
Tacana & 28.08 & 24.30 \\
Iracema & 27.58 & 23.32 \\
Mexico 23 & 23.25 & 16.83 \\
Piracununga & 18.31 & 19.75 \\
CMC 40 & 17.95 & 18.11 \\
M Mex 59 & 17.35 & 16.17 \\
Llanera & 16.96 & 18.37 \\
M Col 673 & 14.21 & 12.35 \\
Del Pais & 13.04 & 11.51 \\
Badwoman & 11.68 & 10.06 \\
Twelve Month & 8.65 & 5.59 \\
M Mex 55 & 8.25 & 12.01 \\
Four Month & 6.79 & 5.01 \\
Chinese Stick & 6.46 & 4.35 \\
M Col 22 & 6.32 & 9.96 \\
Uncle Mack & 5.38 & 8.07 \\
Brancha Butterstick & 4.66 & 6.45 \\
Bitterstick & 4.43 & 2.26 \\
R. Singh & 3.84 & 5.62 \\
L. H. 2 & 2.92 & 1.89 \\
Coefficient of variation, \% & 16.98 & 33.16 \\
LSD (0.05) & 3.46 & 4.86 \\
\hline
\end{tabular}


facilities were installed. After drying, land preparation began and consisted of plowing, harrowing, and levelling. Inter-bed ditches $(0.5 \mathrm{~m} \times 0.5$ m) were made $22 \mathrm{~m}$ apart and connected to main drains $(1 \mathrm{~m} \times 1 \mathrm{~m})$.

Lime was applied as aragonite at 6.72 tons/ha 1 mo before sowing. Prior to planting, urea, triple superphosphate, and muriate of potash were broadcast at rates of $84 \mathrm{~N}, 33.5 \mathrm{P}_{2} \mathrm{O}_{5}$, and $100.5 \mathrm{~K}_{2} \mathrm{O}(\mathrm{kg} / \mathrm{ha})$, respectively. A similar amount was banded at a $15-\mathrm{cm}$ radius from the plant and 4 to $5 \mathrm{~cm}$ deep, 4 mo after planting.

To correct for possible minor element deficiencies a prophylactic TABLE 3.-Dry-root yield of 20 varieties of cassava at 12 months on marginal peats and peaty clays of Guyana

\begin{tabular}{|c|c|c|}
\hline \multirow{2}{*}{ Cultivar } & \multicolumn{2}{|c|}{ Dry-root yield on indicated soil } \\
\hline & Anira peat No. 20 & Inki clay No. 100 \\
\hline & $T / h a$ & $T / h a$ \\
\hline Badwoman & 4.37 & 3.19 \\
\hline Bitterstick & 1.68 & .86 \\
\hline Brancha Butterstick & 1.66 & 2.39 \\
\hline Chinese Stick & 2.31 & 1.56 \\
\hline CMC 40 & 5.40 & 4.82 \\
\hline Del País & 4.37 & 3.67 \\
\hline Four Month & 2.60 & 1.85 \\
\hline Iracema & 10.16 & 8.44 \\
\hline L.H. 2 & 1.03 & .68 \\
\hline Llanera & 6.85 & 6.47 \\
\hline $\mathrm{M} \mathrm{Col} 22$ & 2.16 & 3.14 \\
\hline M Col 673 & 5.92 & 4.87 \\
\hline M Mex 23 & 8.41 & 5.56 \\
\hline M Mex 55 & 2.88 & 3.83 \\
\hline M Mex 59 & 5.33 & 5.82 \\
\hline Piracununga & 6.36 & 5.66 \\
\hline R. Singh & 1.51 & 2.13 \\
\hline Tacana & 9.60 & 8,32 \\
\hline Twelve Month & 3.26 & 2.03 \\
\hline Uncle Mack & 2.02 & 2.56 \\
\hline Coefficient of variation & 17.16 & 32.65 \\
\hline $\operatorname{LSD}(0.05)$ & 1.26 & 1.61 \\
\hline
\end{tabular}

application of $45 \mathrm{~kg} / \mathrm{ha}$ of fritted trace elements (B R-12) was supplied with the first fertilizer application. B R-12 contains $5.5 \% \mathrm{MnO}_{2}, 5.4 \%$ $\mathrm{Fe}_{2} \mathrm{O}_{3}, 11.5 \% \mathrm{ZnO}, 1.0 \% \mathrm{CuO}, 7.0 \% \mathrm{~B}_{2} \mathrm{O}_{3}$, and $0.2 \% \mathrm{MoO}_{3}$.

Cuttings $15 \mathrm{~cm}$ long were row-planted in plots $9 \times 4.6 \mathrm{~m}$. Each row contained 10 experimental plants surrounded by border rows. All observations were from 20 test plants taken from two central rows. Prior to planting, cuttings were immersed in a suspension of Dithane ${ }^{3} \mathrm{M}-45(0.04 \%$

\footnotetext{
${ }^{3}$ Trade names are used in this publication solely for the purpose of providing specific information. Mention of a trade name does not constitute a guarantee or warranty of equipment or materials by the Agricultural Experiment Station of the University of Puerto Rico or an endorsement over other equipment or materials not mentioned.
} 
A.I.) and monocrotophos (0.06\% A.I.) for $0.5 \mathrm{~h}$ and planted inclined in furrows 8 to $10 \mathrm{~cm}$ deep. Plots were manually weeded as often as necessary.

Moderately severe attacks of cassava bud-worm [Phlyctaenodes bifilalis Hamp.) (Pyraustidae:Lepidoptera)] were observed from the third month and persisted through harvest. Sprays of Trichlorofon (Depterex) at $1 \mathrm{~kg} \mathrm{A.I./ha,} \mathrm{at} 3$ weekly intervals were used to control this pest.

Both experiments were harvested 361 days after planting. Before harvesting, plant height (soil surface to the distal growing tip) and stem

TABLE 4.-Useful fresh-root yield of 20 cultivars of cassava at 12 months on marginal peats and peaty clays of Guyana

\begin{tabular}{lcc}
\hline & \multicolumn{2}{c}{ Useful root yield in indicated soil } \\
\cline { 2 - 3 } & Anira peat No. 20 & Inki clay No. 100 \\
\hline & $T / h a$ & T/ha \\
Badwoman & 10.04 & 8.66 \\
Bitterstick & 3.65 & 1.93 \\
Brancha Butterstick & 3.92 & 5.47 \\
Chinese Stick & 5.49 & 3.72 \\
CMC 40 & 15.50 & 15.25 \\
Del País & 11.38 & 9.64 \\
Four Month & 5.64 & 4.27 \\
Iracema & 24.21 & 21.13 \\
L.H. 2 & 2.53 & 1.66 \\
Llanera & 14.71 & 15.67 \\
M Col 22 & 5.32 & 8.40 \\
M Col 673 & 12.30 & 10.54 \\
M Mex 23 & 19.92 & 14.43 \\
M Mex 55 & 7.02 & 9.88 \\
M Mex 59 & 14.86 & 13.40 \\
Piracununga & 15.92 & 16.55 \\
R. Singh & 3.28 & 4.83 \\
Tacana & 24.57 & 20.90 \\
Twelve Month & 7.28 & 4.74 \\
Uncle Mack & 4.52 & 6.83 \\
\hline Coefficient of variation (\%) & 17.21 & 10.15 \\
LSD (0.05) & 3.02 & 3.78 \\
\hline
\end{tabular}

diameter at the soil surface were recorded. At harvest, observations were made on number of shoots per cutting, number of roots per plant, largest root diameter, fresh root weight, and fresh weight of stems and leaves.

Laboratory analyses consisted of dry matter content determinations of unpeeled roots and edible fresh-matter content (ratio of peeled to unpeeled root). Dry and edible matter determinations were made on three 200-g subsamples of material taken from the proximal, center, and distal portions of approximately $2 \mathrm{~kg}$ of freshly-harvested roots/plot. Drying was made at 55 to $60^{\circ} \mathrm{C}$ for $48 \mathrm{~h}$ in a forced-draft oven. 
A composite sample $(8 \mathrm{~kg})$ of freshly-harvested roots of each cultivar was allowed to remain on the field plots for storage life determinations.

\section{RESULTS AND DISCUSSION}

The cultivars obtained from Brazil outyielded all the others on the Inki clay and ranked among the best on the Anira peat (table 2). The Tacana

TABLE 5.-Plant height, total plant yield, yield of stems and leaves, and harvest index of 20 cassava cultivars at 12 months on marginal peats and peaty clays of Guyana

\begin{tabular}{|c|c|c|c|c|c|c|c|c|}
\hline \multirow[b]{2}{*}{ Cultivar } & \multicolumn{4}{|c|}{ Anira Peat No. 20} & \multicolumn{4}{|c|}{ Inki Clay No. 100} \\
\hline & $\begin{array}{l}\text { Plant } \\
\text { height }\end{array}$ & $\begin{array}{c}\text { Total } \\
\text { plant } \\
\text { weight }\end{array}$ & $\begin{array}{l}\text { Stems and } \\
\text { leaves }\end{array}$ & $\begin{array}{l}\text { Harvest } \\
\text { index }\end{array}$ & $\begin{array}{l}\text { Plant } \\
\text { height }\end{array}$ & $\begin{array}{l}\text { Total } \\
\text { plant } \\
\text { weight }\end{array}$ & $\begin{array}{l}\text { Stems and } \\
\text { leaves }\end{array}$ & $\begin{array}{c}\text { Harvest } \\
\text { index }\end{array}$ \\
\hline & $M$ & $T / h a$ & $T / h a$ & & $M$ & $T / h a$ & $T / h a$ & \\
\hline Badwoman & 1.22 & 22.66 & 10.99 & 0.51 & 1.20 & 19.91 & 7.26 & 0.62 \\
\hline Bitter Stick & 1.62 & 26.26 & 21.83 & .17 & 1.80 & 14.84 & 12.57 & .16 \\
\hline $\begin{array}{l}\text { Brancha } \\
\text { Butterstick }\end{array}$ & 1.31 & 13.24 & 8.58 & .34 & 1.45 & 12.90 & $6.4 \mathrm{I}$ & .51 \\
\hline $\begin{array}{l}\text { Chinese } \\
\text { Stick }\end{array}$ & 1.32 & 18.20 & 11.74 & .34 & 1.36 & 16.50 & 10.14 & .25 \\
\hline CMC 40 & 1.60 & 27.28 & 9.33 & .66 & 1.62 & 29.87 & 11.76 & .61 \\
\hline Del País & 1.35 & 24.86 & 11.79 & .52 & 1.51 & 22.79 & 11.27 & .50 \\
\hline Four Month & 1.14 & 18.28 & 11.49 & .38 & 1.27 & 12.92 & 7.90 & .39 \\
\hline Iracema & 1.74 & 44.70 & 17.12 & .62 & 1.48 & 36.42 & 13.11 & .63 \\
\hline L.H. 2 & 1.43 & 10.16 & 7.24 & .29 & 1.47 & 6.80 & 4.91 & .31 \\
\hline Llanera & 1.45 & 29.45 & 12.49 & .58 & 1.40 & 29.22 & 10.85 & .62 \\
\hline $\mathrm{M} \mathrm{Col} 22$ & .69 & 9.23 & 2.91 & .69 & .75 & 14.25 & 4.28 & .68 \\
\hline M Col 673 & 1.51 & 26.71 & 12.51 & .53 & 1.50 & 24.23 & 11.87 & .50 \\
\hline M Mex 23 & 1.51 & 37.61 & 14.36 & .62 & 1.50 & 29.88 & 13.05 & .58 \\
\hline M Mex 55 & .72 & 12.36 & 4.10 & .67 & .70 & 17.46 & 5.44 & .68 \\
\hline M Mex 59 & 1.06 & 27.17 & 9.82 & .64 & 1.26 & 26.75 & 10.58 & .62 \\
\hline Piracununga & 1.00 & 24.62 & 6.31 & .75 & 1.04 & 24.50 & 4.85 & .79 \\
\hline R. Singh & .80 & 7.25 & 3.41 & .54 & 1.16 & 9.66 & 4.03 & .59 \\
\hline Tacana & 1.79 & 41.96 & 13.88 & .67 & 1.60 & 35.21 & 10.91 & .69 \\
\hline Twelve Month & 1.47 & 19.26 & 10.61 & .45 & 1.38 & 14.62 & 9.02 & .38 \\
\hline Uncle Mack & 1.05 & 11.06 & 5.68 & .41 & 1.11 & 13.17 & 5.10 & .59 \\
\hline $\begin{array}{l}\text { Coefficient of } \\
\text { Variation } \\
(\%)\end{array}$ & 8.13 & 14.56 & 40.61 & 11.90 & 16.16 & 29.17 & 33.76 & 9.34 \\
\hline $\operatorname{LSD}(0.05)$ & .18 & 5.45 & 6.93 & .10 & .27 & 7.58 & 5.21 & .08 \\
\hline
\end{tabular}

cultivar produced $28.08 \mathrm{t} / \mathrm{ha}$ of fresh roots on the Anira peat, and 24.30 t/ha on the Inki clay, outyielding the poorest performer, L.H. 2, by 10and 13-fold, respectively. Viewed collectively, the introductions yielded $300 \%$ more fresh roots than the local cultivars. Cultivars M Mex 23 and M Mex 59 ranked among the seven best yielders on both soils. This finding supports previous results (7). Among local cultivars, Badwoman yielded highest on both soils, producing 11.68 and $10.06 \mathrm{t} / \mathrm{ha}$ of roots on 
the Anira peat and the Inki clay, respectively. In general, there was a tendency among cultivars to yield lower $(11.60 \mathrm{t} / \mathrm{ha})$ on the Inki clay than when grown on the Anira peat (12.31 t/ha).

This suggests the possibility of immediate yield increase by varietal screening. Noting that there were only two cultivars that exceeded 20 t/ha out of a germplasm collection of 20 , it appears necessary to start a selection program with a very wide variability of germplasm.

\section{DRY MATTER CONTENT}

Dry-root yields are presented in table 3. Dry matter varied between 30 and $42 \%$ on the Anira peat and ranged from 27 to $39 \%$ on the Inki clay.

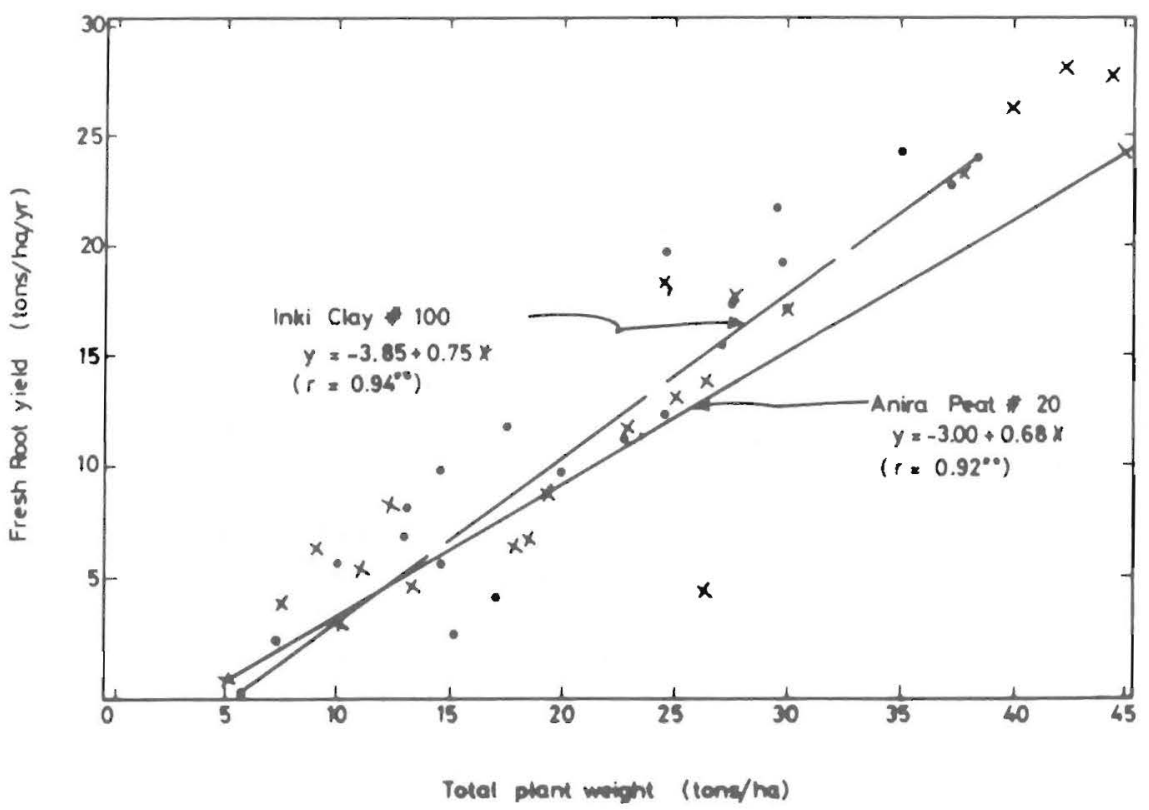

FiG. 1.-Relationship between total plant weight and fresh-root yield of cassava grown on marginal peats and peaty clays in Guyana.

Irrespective of soil type, $\mathrm{M}$ Col 673 contained the least amount of moisture. This is in accord with a previous trial in which this variety was compared with 11 others. On the Anira peat, dry-root yields ranged from 1.03 to $10.16 \mathrm{t} / \mathrm{ha}$, whereas, on the Inki clay, root dry matter varied from 0.68 to $8.44 \mathrm{t} / \mathrm{ha}$ (7). As in the fresh-root data, the introduced cultivars significantly outyielded their local counterparts.

\section{EDIBLE ROOT CONTENT}

Edible fresh-root content (table 4) indicates that irrespective of cultivar and soil, the peeled- to unpeeled-root ratio was essentially the same, an 
average of 0.85 for all cultivars. Viewed differently, the outer and inner peel of the root constitutes about $15 \%$ of its fresh weight. As in the case of fresh root weights, the Brazilian cultivars Tacana and Iracema outyielded the others in terms of edible yield on both soils.

The data presented in tables 2, 3, and 4 demonstrate that, despite their apparent unsuitability for conventional agriculture, Guyana's marginal peats and peaty clay soils can be made rather productive when properly managed. Considering that the present national production of cassava is estimated at 7 to 10 tons/ha and the high yields obtained in these

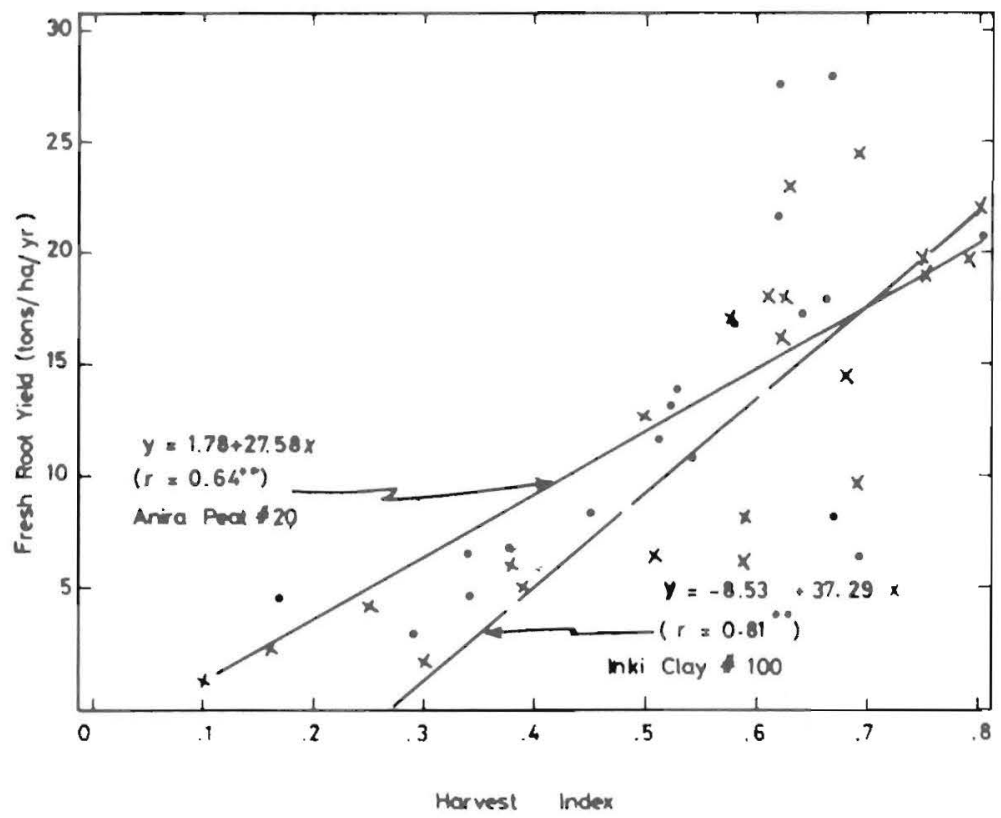

Fig. 2,-Relationship between harvest index and fresh-root yield of cassava grown on marginal peats and peaty clays in Guyana.

experiments, it is important that these soils be further studied with the aim of increasing their productivity. Also, it has been shown that a yield increase can be achieved immediately if these soils are planted with suitable cassava cultivars.

\section{PLANT CHARACTERISTICS}

Plant height, total plant fresh weight, weight of stems and leaves, and harvest index are summarized in table 5. Each of these agronomic characteristics differed significantly between cultivars on both soils. Irrespective of soil type, M Col 22 and M Mex 55 were the smallest 
cultivars, measuring less than $1 \mathrm{~m}$. Also, these cultivars were among the lowest producers of stems and leaves but yielded relatively high freshroot weight. Hence, they were characterized by a high harvest index. This situation can be contrasted with other cultivars (Bitter Stick and Chinese Stick) that were among the tallest and highest producers of stems and leaves but which produced relatively low fresh-root weight and thus had a low harvesting index. On the other hand, cultivars such as Iracema, M Mex 23, and Tacana grew vigorously, produced large quantities of stems

TABLE 6.-Number of shoots arising from a stem cutting, stem diameter, number of edible roots per plant, and maximum root diameter at 12 months of 20 cultivars of cassava on marginal peats and peaty clays of Guyana

\begin{tabular}{|c|c|c|c|c|c|c|c|c|}
\hline \multirow[b]{2}{*}{ Cultivars } & \multicolumn{4}{|c|}{ Anira Peat No. 20} & \multicolumn{4}{|c|}{ Inki Clay No. 100} \\
\hline & $\begin{array}{c}\text { Shoots } \\
\text { per plant }\end{array}$ & $\begin{array}{l}\text { Stem di- } \\
\text { ameter }\end{array}$ & $\begin{array}{l}\text { Edible } \\
\text { roots per } \\
\text { plant }\end{array}$ & $\begin{array}{l}\text { Maxi- } \\
\text { mum } \\
\text { root di- } \\
\text { ameter }\end{array}$ & $\begin{array}{c}\text { Shoots } \\
\text { per plant }\end{array}$ & $\begin{array}{l}\text { Stem di- } \\
\text { ameter }\end{array}$ & $\begin{array}{l}\text { Edible } \\
\text { roots per } \\
\text { plant }\end{array}$ & $\begin{array}{l}\text { Maxi- } \\
\text { mum } \\
\text { root di- } \\
\text { ameter }\end{array}$ \\
\hline & No & $\mathrm{Cm}$ & No & $\mathrm{Cm}$ & No & $\mathrm{Cm}$ & No & $\mathrm{Cm}$ \\
\hline Badwoman & 2.07 & 1.55 & 3.98 & 5.05 & 2.46 & 1.73 & 4.12 & 4.59 \\
\hline Bitterstick & 1.58 & 2.09 & 4.36 & 3.97 & 1.62 & 2.16 & 2.91 & 3.14 \\
\hline $\begin{array}{l}\text { Brancha } \\
\text { Butterstick }\end{array}$ & 1.50 & 1.73 & 2.55 & 4.03 & 1.53 & 1.80 & 2.78 & 3.75 \\
\hline $\begin{array}{c}\text { Chinese } \\
\text { Stick }\end{array}$ & 1.47 & 2.14 & 3.45 & 3.96 & 2.14 & 2.07 & 4.08 & 3.38 \\
\hline $\mathrm{CMC} 40$ & 2.00 & 1.91 & 4.06 & 7.23 & 2.10 & 1.98 & 4.35 & 7.15 \\
\hline Del Pais & 1.61 & 1.87 & 5.34 & 0.07 & 1.84 & 2.16 & 9.20 & 5.17 \\
\hline Four Month & 1.91 & 1.88 & 4.22 & 4.15 & 2.13 & 1.80 & 5.37 & 3.96 \\
\hline Iracema & 3.22 & 1.99 & 5.81 & 7.24 & 3.45 & 1.86 & 5.73 & 6.37 \\
\hline L.H. 2 & 1.57 & 1.72 & 2.60 & 3.55 & 1.68 & 1.74 & 1.55 & 3.02 \\
\hline Llanera & 1.17 & 2.27 & 3.99 & 3.96 & 1.47 & 2.02 & 5.41 & 7.31 \\
\hline M Col 22 & 1.75 & 1.71 & 4.23 & 4.66 & 1.62 & 1.67 & 4.70 & 4.60 \\
\hline M Col 673 & 1.45 & 2.23 & 3.88 & 4.77 & 1.70 & 2.10 & 3.99 & 5.50 \\
\hline M Mex 23 & 1.48 & 2.23 & 3.47 & 6.27 & 1.37 & 2.35 & 5.06 & 5.41 \\
\hline M Mex 55 & 1.28 & 1.81 & 3.73 & 4.76 & 1.35 & 1.80 & 3.89 & 5.36 \\
\hline M Mex 59 & 1.56 & 2.17 & 3.97 & 5.37 & 1.73 & 2.11 & 3.83 & 5.56 \\
\hline Piracununga & 1.98 & 1.62 & 5.28 & 7.51 & 2.24 & 1.67 & 5.51 & 6.57 \\
\hline R. Singh & 1.72 & 1.53 & 3.38 & 3.63 & 1.91 & 1.64 & 3.40 & 3.71 \\
\hline Tacana & 1.97 & 2.30 & 6.56 & 7.87 & 2.02 & 2.14 & 6.20 & 7.16 \\
\hline $\begin{array}{l}\text { Twelve } \\
\text { Month }\end{array}$ & 1.95 & 2.13 & 4.57 & 4.17 & 1.88 & 2.03 & 3.09 & 3.54 \\
\hline Uncle Mack & 1.90 & 1.66 & 2.70 & 4.41 & 2.39 & 1.74 & 4.70 & 4.21 \\
\hline Grand Mean & 1.76 & 1.97 & 4.11 & 5.22 & 1.93 & 1.93 & 4.49 & 4.97 \\
\hline $\begin{array}{l}\text { Standard Er- } \\
\quad \text { ror }\end{array}$ & $.4 \mathrm{I}$ & .10 & .69 & .38 & .46 & .48 & .74 & 1.03 \\
\hline $\begin{array}{l}\text { Coefficient of } \\
\text { Variation } \\
(\%)\end{array}$ & $28.4 \mathrm{I}$ & 6.40 & 17.27 & 8.81 & 37.30 & 39.37 & 26.07 & 20.12 \\
\hline L.S.D. $(0.05)$ & .83 & 1.30 & 1.40 & .07 & .91 & .96 & 1.47 & 2.05 \\
\hline
\end{tabular}


and leaves and, consequently, higher root yields. In addition, they were characterized by a high harvest index. These results show that high total plant weight and harvest index are very important in obtaining high yields. Indeed, there is a highly significant relation between total plant weight and root yield (fig. 1, $r=0.92$ and 0.94) for the Anira peat and Inki Clay, respectively; and between harvest-index and root-fresh yield

TABLE 7.-Days to onset of primary and secondary root deterioration of 20 cassava cultivars grown on Anira peat No. 20 and Inki clay No. 100 in Guyana, and stored under field conditions '

\begin{tabular}{|c|c|c|c|c|}
\hline \multirow{3}{*}{ Cultivars } & \multirow{2}{*}{\multicolumn{2}{|c|}{$\begin{array}{c}\text { Anira Peat No. } 20 \\
\text { Deterioration }\end{array}$}} & \multirow{2}{*}{\multicolumn{2}{|c|}{$\begin{array}{c}\text { Inki Clay No. } 100 \\
\text { Deterioration }\end{array}$}} \\
\hline & & & & \\
\hline & Primary & Secondary & Primary & Secondary \\
\hline Badwoman & 6 & 8 & 6 & 8 \\
\hline Bitter Stick & 5 & 7 & 6 & 8 \\
\hline Brancha Butterstick & 6 & 8 & 6 & 9 \\
\hline Chinese Stick & $\Leftrightarrow$ & 8 & 7 & 10 \\
\hline CMC 40 & 6 & 7 & 5 & 7 \\
\hline Del País & 6 & 8 & 7 & 9 \\
\hline Four Month & 6 & 7 & 6 & 8 \\
\hline Iracema & 6 & 9 & 6 & 8 \\
\hline L.H. 2 & 5 & 7 & 6 & 8 \\
\hline Llanera & 6 & 9 & 7 & 9 \\
\hline $\mathrm{M} \mathrm{Col} 22$ & 5 & 7 & 6 & 8 \\
\hline M Col 673 & 5 & 7 & 6 & 8 \\
\hline M Mex 23 & 6 & 8 & 6 & 9 \\
\hline M Mex 55 & 6 & 8 & 6 & 9 \\
\hline M Mex 59 & 6 & 9 & 7 & 10 \\
\hline Piracununga & 5 & 7 & 6 & 9 \\
\hline R. Singh & 6 & 8 & 5 & 8 \\
\hline Tacana & 6 & 8 & 6 & 9 \\
\hline Twelve Month & 5 & 7 & 5 & 8 \\
\hline Uncle Mack & 6 & 8 & 6 & 9 \\
\hline Grand Mean & 5.7 & 7.8 & 6.1 & 8.6 \\
\hline
\end{tabular}

${ }^{1}$ Primary deterioration was considered to have started with the appearance of fine blueblack streaks in the root vascular tissue. Secondary deterioration was considered to have occurred when root tissues became soft.

(fig. 2, $r=0.64$ and 0.81 ) for these two soils. Similar results have been reported by The Centro Internacional de Agricultura Tropical, Colombia (2).

On the average, all cultivars produced more than one stem per planted cutting irrespective of soil type (table 6). However, there was no significant relationship between number of stems per plant and root yield. This is in disagreement with earlier work by Chew in Malaya (4). Stem 
diameter differed significantly among cultivars on both soils, but was not related to root yield. Highest yielding cultivars produced significantly more and thicker roots than their lower yielding counterparts. Furthermore, number of root tubers per plant was significantly correlated with yield ( $r=0.69$ on Anira peat and 0.95 on Inki clay). Implicit in these findings is that both root number and root bulkiness are important components for high yield.

\section{POSTHARVEST SHELF LIFE}

Quality of freshly-harvested root was good for all 20 varieties. Thereafter, at least 5 days had elapsed before primary deterioration or evidence of vascular streaking occurred (table 7). On both soils, at least 8 days had elapsed before $60 \%$ of the cultivars had begun to show cellular disintegration (secondary deterioration). Root deterioration was slower on the Inki clay than on the other soil type. Storage life appeared to be independent of cultivar.

These studies show that roots free of mechanical injury can tolerate several days in the field before being taken to processing plants. However, where delays are inevitable, the time lapse between harvest and processing should not exceed $48 \mathrm{~h}$.

\section{RESUMEN}

Veinte cultivares de yuca de procedencia local e introducciones se evaluaron durante un período de crecimiento de 12 meses. Esta prueba se realizó para determinar si los suelos marginales de Guyana, tipos turba Anira \#20 e Inki arcilloso \#100 eran adecuados para dicha cosecha. Se obtuvo material de propagación de Brasil, Colombia, México, Puerto Rico y Guyana. Los cultivares Tacana e Iracema, ambos del Brasil, fueron los de más altos rendimientos con $28 \mathrm{t} / \mathrm{ha}$ de raíces en el suelo Anira y $24 \mathrm{t} / \mathrm{ha}$ en el suelo Inki. La mayoría de las introducciones superaron a los cultivares locales. El cultivar nativo de mayor rendimiento fue Badwoman con 12 y $10 \mathrm{t} / \mathrm{ha}$ en los suelos Anira e Inki, respectivamente. El cultivar M Col 673 fue el de contenido más elevado en materia seca: $40 \%$ en ambos suelos. La cantidad de materia fresca media utilizable fue de 0.85 , básicamente similar en todos los casos. La relación entre el peso total de la planta y el rendimiento de raíces comestibles fue altamente significativa en ambos suelos ( $r=0.92$ y 0.94 ). También fue igualmente significativa la relación entre el indice de cosecha y el rendimiento de raíces ( $r=0.64$ y 0.81 ). Se comprobó que el número de tallos provenientes de un cangre (esqueje) y el diámetro del tallo al cosechar no están relacionados con el rendimiento. Sin embargo, la correlación entre el número de raíces comestibles por planta y el rendimiento fue altamente significativa ( $r$ $=0.69$ y 0.54$)$. También fue significativa la relación entre el grosor de la raíz y el rendimiento $(r=0.92$ y 0.95$)$ en ambos suelos. Bajo condiciones de campo, todos los cultivares se conservaron bien por 5 días antes de que comenzaran a deteriorarse.

\section{LITERATURE CITED}

1. Booth, R. H., 1975. Cassava Storage: Post-harvest deterioration and storage of fresh cassava roots, Series EE 16, Centro Internacional de Agricultura Tropical (C.I.A.T.) Cali, Colombia, S. A.

2. Centro Internacional de Agricultura Tropical (C.I.A.T.), 1975. Cassava production systems, Cali, Colombia, S. A., Ann. Rep.

3. Centro Internacional de Agricultura Tropical (C.I.A.T.), 1973. Ann. Rep. Cali, Colombia, S. A. 
4. Chew, W. Y., 1974. Yields of some varieties of tapioca (Manihot utilissima Pohl) grown on Malaysian peat as affected by different planting methods, plant densities, fertilizers and growth periods, Malays. Agric. J. 49(3): 393-402.

5. Mahadeo, C., 1975. Soil survey-New land, Tech. Rep., Agric. Dep., Bookers Sugar Estates Ltd., Guyana.

6. Steele, J. G., and Ramdin, H. N., 1975. Soil resources of Guyana, Min. Agric., Cent. Agric. Stn., Mon Repos.

7. Wahab, A. H., 1976. Characteristics of indigenous and introduced cultivars of cassava, paper presented to the IV International Symposium on Tropical Root Crops, Proc. 4th Symposium, Int. Soc. Trop. Root Crops and Centro Internacional de Agricultura Tropical (CIAT), 131-7, Cali, Colombia, August 1-8. 